\title{
Chemical composition and activity of bark and leaf extracts of pinus halepensis and olea europaea grown in AL-Jabel AL-Akhdar region, Libya against some plant phytopathogens
}

\begin{abstract}
The objective of this study was to identify the chemical composition and antimicrobial activity of acetone extracts of Pinus halepensis Mill (needles and bark) and Olea europaea L. (leaves and bark) obtained from three different altitudes in AL-Jabal ALAkhder, Libya. The chemical compositions were analyzed by GC/MS. The analyses of the extracts from needles of $P$. halepensis led to the identification of 38,15 and 18 different components, representing $93.34,100$ and $97.00 \%$ of the total extract at three different altitudes $(125,391$ and 851 respectively). However, the extracts from bark contained 6, 4 and 8 compounds, representing $100 \%$ of the total extract at three different altitudes, respectively. For the leaf extracts from O. europea, 5, 8 and 10 compounds were identified, representing $100 \%$ of the total extracts at three different altitudes $(125,391$ and 851 respectively). However, the crud extracts from bark led to the identification of 13,16 and 15 compounds, representing $97.55,99.70$ and $98.05 \%$ of the total extract at three different altitudes, respectively. The chemical classes of the detected compounds confirmed that these extracts contained a complex mixture consisting of sugars, monoterpene hydrocarbons, sesquiterpenes, diterpenes, diterpenoids, terpenophenolics, triterpenes, tetraterpenoids, phenylethanoids, steroids, resins and phthalates. Four pathogenic bacteria and one fungal strain were used to determine the antimicrobial activity. The extracts exhibited antibacterial potency with varying degrees of inhibition with MIC values ranging from 480 to $1300 \mathrm{mg} / \mathrm{L}$ and the best MICs values observed were $525,530,410$ and $645 \mathrm{mg} / \mathrm{L}$ against the growth of Agrobacterium tumefaciens, Erwinia carotovora, Corynebacterium fascians and Pseudomonas solanacearum, respectively for the extract from $O$. europaea at altitude I. The extracts all extracts exhibited a significant antifungal potency against Botrytis cinerea with varying degrees of inhibition of growth with $\mathrm{EC}_{50}$ values ranging from 71.10 to $154.71 \mathrm{mg} / \mathrm{L}$.
\end{abstract}

Keywords: pinus halepensis, olea europaea, acetone extracts, antibacterial activity, antifungal activity, GC/MS analysis
Volume 3 Issue 3 - 2017

\author{
Ahmed SO Mohareb,' Ibrahim EA \\ Kherallah,' Mohamed El Badawy,' Mohamed \\ ZM Salem,' Hameda A Yousef ${ }^{1,3}$ \\ 'Department of Forestry and Wood Technology, Alexandria \\ University, Egypt \\ ${ }^{2}$ Department of Pesticide Chemistry and Technology,Alexandria \\ University, Egypt \\ ${ }^{3}$ Department of Forestry and Range Sciences, University of \\ Omar Al Mukhtar, Libya
}

Correspondence: Mohammed El Badawy, Department of Pesticide Chemistry and Technology, Faculty of Agriculture, Alexandria University, 21545 El-Shatby, Alexandria, Egypt, Tel 002039575269, Fax 002035972780,

Email m_eltaher@yahoo.com

Received: March 04, 2017| Published: June 14, 2017
Abbreviations: GC, gas chromatography; MS, mass spectrometry; FID, flame ionization detector; EI, electron impact ionization; MICs, minimum inhibitory concentrations; NB, nutrient broth; DMSO, dimethyl sulfoxide; PDA, potato dextrose agar

\section{Introduction}

Al-Jabal Al-Akhdar region (Libya) has highest species diversity and having distinct environmental characteristics associated with evergreen forest along with the Mediterranean from the Atlas Mountains to the Levant, and it has an environment similar to other regions in Southern Europe such as Italy, the Greek islands and Turkey. ${ }^{1}$ The number of plant species reach up of 1100 species from the total of plant species in Libya (2000 species) with about 75 species of plants that grow only in AL-Jabal AL Akhdar and have been served for as basis of traditional medicinal systems for thousands of years. ${ }^{1-5}$ In addition, such plants produce a remarkable diverse array of over $5,00,000$ low and high molecular mass natural products which are known as secondary metabolites, which can be used as an alternative form of health care as well as screening for active compounds that have significant effects against human and plant pathogens., ${ }^{2,6-8}$ Cupressus sempervirens; Juniperus phoenicea, Olea europaea and Pinus halepensis are a large species of trees which grew widely in temperate regions include Al-Jabal Al-Akhdar region, Libya and have been used in traditional medicine in many part of the world. ${ }^{1,9-13}$

Historically, olive leaves and fruits of Olea europaea were used for the treatment of malaria and associated fever. ${ }^{14}$ The different parts and fruits of this tree are rich in phenolic substances including hydroxytyrosol, tyrosol, caffeic acid, p-coumaric acid, vanillic acid, vanillin, oleuropein, luteolin, diosmetin, rutin, verbascoside, luteolin7-glucoside, apigenin-7-glucoside, and diosmetin-7-glucoside. ${ }^{15,16}$ These valuable products possess important antioxidant and antibacterial effects ${ }^{14,17-20}$ and have an ancient history of nutritional, medicinal and traditional usages especially as an important part of the Mediterranean. ${ }^{21-23}$ Phytochemical screening of aqueous extract of O. europaea leaves revealed the presence of flavonoids, saponins and steroid, which demonstrated the best inhibition against some bacterial strains..$^{24}$ Pinus halepensis Miller is a steno-mediterranean species distributed along the coasts and in the islands, it prefers 
warmer calcareous areas like Libya, Italy, Algeria, Greece, Morocco, and Turkey, where it also succeeds in colonizing the less hospitable rocks because of its springiness. ${ }^{25-27}$ The genus Pinus (Pinaceae) comprises 250 species and is widespread in the northern hemisphere, especially in the Mediterranean region, Caribbean area, Asia, Europe, North and Central America. ${ }^{25,28,29}$ The extracts of $P$. halepensis are rich in secondary metabolites like terpenoids, essential oils, terpenes, turpentine and phenolic compounds. ${ }^{28,30-38}$ Recently, an increase interest in natural substances extracted from such plants has been observed in literatures due to their significant impact from an environmental point of view, as well as to find effective alternatives to the industrially synthesized chemicals. ${ }^{3,39-42}$ Therefore, the objective of this study was to analyze the chemical composition of acetone extracts of Pinus halepensis Mill (needles and bark) and Olea europaea L. (leaves and barks), collected from three levels of altitude in AL-Jabal AL-Akhder, Libya, using gas chromatography/mass spectrometry (GC/MS). The $\mathrm{GC} / \mathrm{MS}$ is an analytical instrument that a hyphenated system of GC and $\mathrm{MS}$ and it is a very compatible technique and the most commonly used technique for the identification and quantification of different substances within a test sample. ${ }^{43}$ The unknown organic compounds in a complex mixture can be determined by interpretation and also by matching the spectra with reference spectra. ${ }^{44}$ Additionally, it can identify trace elements in materials that were previously thought to have disintegrated beyond identification. The percentages of leaf and bark components of selected trees in the present study were estimated from the obtained GC/MS spectra. The influence of altitude on the quantity and quality of the extracts was discussed in details. In addition, the identification of the most effective compounds and the antimicrobial activity against four pathogenic bacteria Agrobacterium tumefaciens, Erwinia carotovora, Corynebacterium fascians and Pseudomonas solanacearum and the fungus Botrytis cinerea have been investigated.

\section{Materials and methods}

\section{Plant materials}

Pinus halepensis Mill (needles and bark), and Olea europaea L. (leaves and bark), were collected from three altitudes in AL-Jabal AL-Akhder, Libya during august 2014, where the trees were selected within three classes of different levels of altitudes. The species were identified and were chosen from three levels of altitude. First level $(125 \mathrm{~m})$ represents the area Alwsita considered as littoral zone near to the Mediterranean Sea. Second level (391m) of Wadi-Alkuf area which includes the area between $200 \mathrm{~m}$ height to $450 \mathrm{~m}$ height above the sea level and third level $(851 \mathrm{~m})$ of Sidi-Alhemre which includes sites that begin height of about greater than 450 meters above the sea level. Collected fresh plant materials were examined and the old, pest-infected leaves were removed. The fresh bark and leaves of each species of tree were washed with clean water and thoroughly dried at room temperature and then ground into powders by an electric mill. The leaves and powdered bark of each tree were stored at room temperature in dark places until they were subjected to the extraction process.

\section{Sample extraction}

The dry extracts $(100 \mathrm{~g})$ of each sample were extracted into acetone $(500 \mathrm{~mL})$ by immersing the powder in the solvent for $48 \mathrm{~h}$ at room temperature in the dark. Acetone was selected as it is more of a nonpolar solvent than others are and most organic molecules present in plant samples are more soluble in it. The contents were then filtered with Whatman No. 1 filter paper. The resulting filtrates were then concentrated with a rotary evaporator at $60^{\circ} \mathrm{C}$ to give a dark colored solid. The extracts were stored in dark bottles and refrigerated at $4{ }^{\circ} \mathrm{C}$ before use. ${ }^{45}$

\section{GC/MS analysis of the extracts}

Acetone extracts was analyzed for their chemical composition by gas chromatography/mass spectrometry $(\mathrm{GC} / \mathrm{MS})^{46,47}$ with the following specifications: A Trace GC Ultra/Mass Spectrophotometer ISQ (Thermo scientific, Austin, TX, USA) instrument equipped with flame ionization detectors (FID) and a direct capillary column TG-5MS (30m $90.25 \mathrm{~mm} 90.251 \mathrm{~m}$ film thickness) apparatus at Central Laboratory, Faculty of Agriculture, Alexandria University; Alexandria, Egypt. Helium (average velocity $39 \mathrm{~cm} \mathrm{~s}^{-1}$ ) was used as the carrier gas (flow rate of $1 \mathrm{~mL} / \mathrm{min}$ ), and the temperature program was $120^{\circ} \mathrm{C} / \mathrm{min}$ raised at $6^{\circ} \mathrm{C} / \mathrm{min}$ to $320^{\circ} \mathrm{C}$, injector temperature was $260^{\circ} \mathrm{C}$ and detector temperature was $320^{\circ} \mathrm{C}$ with post run (off) at $320^{\circ} \mathrm{C}$. Sample $(1 \mu \mathrm{L})$ was injected at $250^{\circ} \mathrm{C}$, with split/split-less injector (50:1 split ratio) in the split less mode flow with $10 \mathrm{~mL} / \mathrm{min}$. All mass spectra were recorded in the electron impact ionization (EI) at 70 electron volts. The mass spectrometer was scanned from 50 $500 \mathrm{~m} / \mathrm{z}$ at five scans per second. Scan time: $1.5 \mathrm{~s}$; mass range: 40 to $300 \mathrm{amu}$. The ion source and transfer line temperatures were set at 200 and $250^{\circ} \mathrm{C}$, respectively. Peak area percent was used for obtaining quantitative data with the Xcalibur ${ }^{\mathrm{TM}}$ Software (Xcalibur 4.0 with Foundation 3.1 SP1, Thermo Scientific Technologies) without using the use of response factor correction. The compounds were identified by comparing their mass spectra with MS library (NIST and Wiley) data. ${ }^{48,49}$ Quantification of the percentage of each component was obtained by integrating the peak area of the chromatogram obtained by FID.

\section{In-vitro antibacterial assay}

Four plant pathogenic bacteria namely, Agrobacterium tumefaciens (Family: Rhizobiaceae), Erwinia carotovora (Family: Enterobacteriaceae), Corynebacterium fascians (Family: Nocardiaceae) and Pseudomonas solanacearum (Family: Pseudomonadaceae) were provided by Department of Pesticide Chemistry and Technology, Faculty of Agriculture, Alexandria University, Egypt. The bacterial strains were maintained on nutrient agar (NA: Peptone 5g, Beef extract $3 \mathrm{~g}, \mathrm{NaCl} 8 \mathrm{~g}$ ), medium at $37^{\circ} \mathrm{C}$. The in vitro antibacterial activities as minimum inhibitory concentrations (MICs) of the extracts were determined by micro dilution broth assay method using 2,3,5-triphenyltetrazolium chloride (TTC, Sigma) as a chromogenic marker. ${ }^{50,51}$ Nutrient broth (NB) medium was used to grow the bacterial strains to a final inoculum size of $5 \times 10^{5} \mathrm{CFU} / \mathrm{mL}$. The extracts were dissolved in dimethyl sulfoxide (DMSO) and diluted with distilled water to obtain a final stock solution of $2000 \mathrm{mg} / \mathrm{L}$. For the broth microdilution test, $20 \mu \mathrm{L}$ of each bacterial suspension in NB medium was added to the wells of a sterile $96-$ well microtitre plate already containing $40 \mu \mathrm{L}$ of serially diluted compounds and $140 \mu \mathrm{L}$ NB medium. The final volume in each well was $200 \mu \mathrm{L}$. Control wells were prepared with culture medium, bacterial suspension, and solvent. The contents of each well were mixed on a micro plate shaker at 200rpm prior to incubation for $24 \mathrm{~h}$ at $37 \pm 2^{\circ} \mathrm{C}$. To indicate respiratory activity, the presence of color was determined after adding $10 \mu \mathrm{L} /$ well of TTC dissolved in water $(0.01 \%$, $\mathrm{w} / \mathrm{v}$ ) and incubated under appropriate cultivation condition for $30 \mathrm{~min}$ in dark. The absorbance was measured at $492 \mathrm{~nm}$ in an Ultra Micro plate Reader (Robonik, PVT.LTD). Positive controls were wells with 
a bacterial suspension. Negative controls were wells with growth medium and the tested compounds. All measurements of MIC values were repeated in triplicate. The MIC was the lowest concentration, where no viability was observed after $24 \mathrm{~h}$ on the basis of metabolic activity.

\section{In-vitro antifungal activity}

A culture of Botrytis cinerea (Pers.) (Moniliaceae; Class: Deuteromycetes), was provided by Department of Pesticide Chemistry and Technology, Faculty of Agriculture, Alexandria University; Alexandria, Egypt. B. cinerea was obtained by growing the fungus in potato dextrose agar medium (PDA) at $26^{\circ} \mathrm{C}$. The antifungal activity on the mycelial growth of $B$. cinerea was tested using mycelia radial growth technique according to Badawy et al. ${ }^{52}$ The extracts were dissolved in DMSO with different concentrations ranging from 50 to $2000 \mathrm{mg} / \mathrm{L}$ and then added to sterilize the PDA medium immediately before pouring into sterilized Petri dishes. Each concentration was tested in triplicate. Parallel controls were maintained with DMSO mixed with PDA medium. Mycelial discs $(0.5 \mathrm{~cm}$ in diameter $)$ of fungus, from an 8-day culture on PDA plates, were transferred aseptically to the center of the Petri dishes. Plates were incubated in the dark at $26^{\circ} \mathrm{C}$. Colony growth diameter was measured when fungal growth in the control had completely covered the Petri dishes. The percent inhibition of mycelial growth was calculated as follows:

$$
\text { Mycelial growth inhibition }(\%)=\left[\frac{(\mathrm{DC}-D T)}{D C}\right] \times 100
$$

Where the DC and DT are average diameters of fungal colonies of control and treatment respectively

\section{Statistical analysis}

The experimental data are presented as mean \pm standard error or standard deviation and the ANOVA was performed and the property values were separated $(P \leq 0.05)$ with the Student-Newman-Keuls (SNK) by the SPSS program (Statistical Package for Social Sciences, version 21.0, United States). The concentration which inhibited 50\% of the fungal mycelial growth $\left(\mathrm{EC}_{50}\right)$ and its corresponding $95 \%$ confidence limits were calculated by probit analysis. ${ }^{53}$

\section{Results and discussion}

\section{The yield of crude acetone extracts}

The data in Table 1 showed that the yield percentage of crud extracts (weight/dry weight of plant) was varied significantly between tree species and the source of extract that obtained from bark or leaves. The data showed that the highest percentages of the yield were found in crude extracts of $O$. europaea leaf with $9.00 \%, 11.7 \%$ and $14.99 \%$ at levels I, II, and III, respectively, while lowest percentages were found in P. halepensis needle extract with $3.75 \%, 3.70 \%$ and $2.39 \%$ at levels I, II, and III respectively. On the other hand, the yield of crud extracts of bark showed highest relatively percentages found in P. halepensis with $6.43 \%, 6.61 \%$ and $3.74 \%$, at levels I, II, and III respectively. Yield of extracts from $O$. europea obtained in our study is lower than that reported by Faiza et al. ${ }^{54}$ who observed that the acetone extract yielded $29.00 \pm 0.06 \%$ compared with methanol, n-butanol and ethyl acetate extracts with values of $24.65 \pm 0.01 \%$, $9.1 \pm 0.01 \%$ and $3.00 \pm 0.05 \%$, respectively, ${ }^{54}$
Table I Mean values of crud extracts yield (\%) isolated from P. halepensis (bark and needles) and 0 . europaea (bark and leaves) at different levels of altitudes

\begin{tabular}{|c|c|c|c|c|}
\hline \multirow{3}{*}{ Altitude } & \multicolumn{4}{|c|}{ Yield (\%)士SD } \\
\hline & \multicolumn{2}{|c|}{ Bark extracts } & \multicolumn{2}{|c|}{ Leaf extracts } \\
\hline & $\begin{array}{l}\text { P. } \\
\text { Halepensis }\end{array}$ & $\begin{array}{l}\text { O. } \\
\text { Europaea }\end{array}$ & $\begin{array}{l}\text { P. } \\
\text { Halepensis }\end{array}$ & $\begin{array}{l}\text { O. } \\
\text { Europaea }\end{array}$ \\
\hline $\mathrm{I}(\mathrm{I} 25 \mathrm{~m})$ & $6.43 a \pm 3.75$ & $4.80 \mathrm{a} \pm 0.93$ & $3.75 \mathrm{a} \pm 1.7 \mathrm{I}$ & $9.00 c \pm 3.99$ \\
\hline II(39Im) & $6.6 \mathrm{Ia} \pm 3.94$ & $4.88 a \pm 1.23$ & $3.70 \mathrm{a} \pm 1.33$ & $1 \mathrm{l} .70 \mathrm{~b} \pm 1.2 \mathrm{I}$ \\
\hline $\mathrm{III}(85 \mathrm{I} \mathrm{m})$ & $3.74 b \pm 1.06$ & $3.85 b \pm 1.47$ & $2.39 b \pm 0.74$ & $14.99 a \pm 0.49$ \\
\hline
\end{tabular}

Chemical composition of crude extracts of $P$. halepensis

GC/MS analyses of the crud extracts from needles of $P$. halepensis led to the identification of 38,15 and 18 different components, representing 93.34, 100, and $97.00 \%$ of the total extract at three different altitudes $(125,391$ and 851 , respectively) (Table 2). However, the crud extracts from bark led to the identification of 6 , 4 , and 8 compounds, representing $100 \%$ of the total extract at three different altitudes (Table 3 ). The identified compounds are listed in Tables $2 \& 3$ according to their elution order on a TG-5MS capillary column. The results show some differences between extracts of three different altitudes in chemical constituents and their amount in each extract. The major components detected in needle extracts (Table 2) at three altitudes were caryophyllene $(3.76 \%, 5.04 \%$ and $8.72 \%), \alpha$-caryophyllene $(0.99 \%, 1.05 \%$ and $1.95 \%), \beta$-cubebene $(1.37,2.44$, and $5.49 \%)$, caryophyllene oxide $(2.22 \%, 3.11 \%$ and $1.11 \%)$, cembrene $(1.56,5.80$, and $5.29 \%)$, dibutyl phthalate (2.54, 1.00, and 0.92\%), 3,7,11-trimethyl -14-(1-methylet hyl)[S-(E,Z,E,E)]-1,3,6,10-cyclotetradecatetraene $\quad(2.30, \quad 14.29$, and $15.84 \%)$, thunbergol $(4.64,30.71$, and $19.46 \%)$, sclareol $(3.78,9.76$, and $6.21 \%)$, anticopalic acid $(3.04,19.20$, and $11.79 \%)$, retinoic acid methyl ester $(2.04,3.00$, and $9.65 \%)$, methyl retinoate $(0.87,1.00$, and $1.39 \%$ ), and mono (2-ethylhexyl) phthalate $(4.07,2.07$, and $0.85 \%$ ). Compounds of isopulegyl acetate, L-glucose, D-fructose,1,3,6trideoxy-3,6 epithio-, sucrose, 1 -sorbose, germacrene $\mathrm{D}, \delta$-cadinene, $\alpha$-cadinol, 17-hydroxy-17-methyl-(17 $\alpha)$-androsta 1,4-dien-3-one, aromadendrene oxide-(2), 1-(+)-ascorbic acid 2,6-dihexadecanoate, phytol, linolenic acid, di-n-octyl phthalate, dehydroabietal, 1-heptatriacotanol, $\alpha$-pimaric acid, androsterone, androstadienedione, 1-Heptatriacotanol, 17-Pentatriacontene, and $\alpha$-sitosterol were only detected in needle extract from altitude I with percentages ranged from 0.77 to $9.28 \%$. However, androstenediol, totarol and retinol were only detected in needle extract from altitude III with percentages $1.51,3.10,1.80 \%$, respectively. The chemical classes of the detected compounds of needle extracts confirmed that these extracts contained a complex mixture consisting of sugars, monoterpene hydrocarbons, sesquiterpenes, diterpenes, diterpenoids, terpenophenolic, steroids, resins, and phthalates (Table 2).

The main components found in three altitudes of crud extracts from the bark of $P$. halepensis summarized in Table 3, were D-glucose, 4,6-o-ethylidene $(40.19,50.40$, and 17.68\%), dibutyl phthalate $(10.88,14.00$, and $2.95 \%)$, di-n-octyl phthalate $(13.04$, 13.10 , and $24.56 \%$ ), and $\beta$-sitosterol $(18.57,22.50$, and $32.08 \%$ ). L-3,4-dihydroxyphenylalanine was detected only in extract of altitude I with $12.33 \%$ of the total weight and disappeared from extracts of altitudes II and III. However, 1-(+)-ascorbic acid 2,6-dihexadecanoate, 
2,2'-dimethyl-6,6'-dinitro-1,1'-biphenyl, 2,2'-methylenebis[3,4,6trichlor oanisole], and lycophyll were only detected in extract of altitude III with $14.52,2.12,2.87$, and $3.22 \%$ of the total weight (Table 3). The data in this table showed that the D-glucose, 4,6-o-ethylidene and $\beta$-sitosterol were the greatest abundance in three extracts followed by di-n-octyl phthalate and butylhexyl phthalate. In addition, the chemical classes of the detected compounds of the bark extracts confirmed that these extracts contain a complex mixture of essential phytochemicals of amino acids, sugars, diterpenes, phthalates, retinol, carotenoids and sterols. Generally, the samples showed a variable composition, which are linked to different sites

Table 2 Chemical composition and main constituents of the crude extracts isolated from P. halepensis needles at different altitudes in AL-Jabal AL-Akhdar region by $\mathrm{GC} / \mathrm{MS}$ analysis and their characteristics. In line with our results, several studies have demonstrated the variability of secondary metabolite production due to climatic and soil conditions. ${ }^{55,56} P$. halepensis is a pioneer and expansionist species that colonizes abandoned agricultural lands characterized by high biodiversity and by the richness of secondary metabolites such as terpenoids and/or phenolic compounds through several processes. ${ }^{55}$ Several phytochemical analyses of $P$. halepensis have been published on terpenes, turpentine and phenolic compounds. ${ }^{30,57-60}$ The literature reports some works on the chemical composition of $P$. halepensis essential oil and extracts from Italy, Turkey, Algeria, Nigeria, Greece, Morocco, Tunisia. ${ }^{28,33,36,61,62}$

\begin{tabular}{|c|c|c|c|c|c|c|c|c|}
\hline \multirow{3}{*}{ Compound name } & \multirow{3}{*}{$\begin{array}{l}\text { Molecular } \\
\text { formula }\end{array}$} & \multirow{3}{*}{ Chemical class } & \multicolumn{6}{|c|}{ Altitude (m) } \\
\hline & & & \multicolumn{2}{|l|}{ I (I $25 \mathrm{~m})$} & \multicolumn{2}{|c|}{ II (39 I m) } & \multicolumn{2}{|c|}{ III (85I m) } \\
\hline & & & Rt (min) & $\begin{array}{l}\text { Area } \\
(\%)\end{array}$ & Rt (min) & $\begin{array}{l}\text { Area } \\
(\%)\end{array}$ & $\begin{array}{l}\text { Rt } \\
\text { (min) }\end{array}$ & $\begin{array}{l}\text { Area } \\
(\%)\end{array}$ \\
\hline Isopulegyl acetate & $\mathrm{C}_{12} \mathrm{H}_{20} \mathrm{O}_{2}$ & $\begin{array}{l}\text { Monoterpene } \\
\text { hydrocarbons }\end{array}$ & 3.89 & 2.25 & - & - & - & - \\
\hline L-Glucose & $\mathrm{C}_{6} \mathrm{H}_{12} \mathrm{O}_{6}$ & Sugars & 4.12 & 1.02 & - & - & - & - \\
\hline $\begin{array}{l}\text { D-Fructose, I,3,6-trideoxy-3,6- } \\
\text { epithio- }\end{array}$ & $\mathrm{C}_{6} \mathrm{H}_{10} \mathrm{O}_{3} \mathrm{~S}$ & Sugars & 4.29 & 3.14 & - & - & - & - \\
\hline Sucrose & $\mathrm{C}_{12} \mathrm{H}_{22} \mathrm{O}_{11}$ & Sugars & 4.38 & 1.16 & - & - & - & - \\
\hline I-Sorbose & $\mathrm{C}_{6} \mathrm{H}_{12} \mathrm{O}_{6}$ & Sugars & 4.92 & 6.79 & - & - & - & - \\
\hline Caryophyllene & $\mathrm{C}_{15} \mathrm{H}_{24}$ & Sesquiterpenes & 5.62 & 3.76 & 5.62 & 5.04 & 5.56 & 8.72 \\
\hline$\alpha$-Caryophyllene & $\mathrm{C}_{15} \mathrm{H}_{24}$ & Sesquiterpenes & 6.1 & 0.99 & 6.11 & 1.05 & 6.05 & 1.95 \\
\hline Germacrene D & $\mathrm{C}_{15} \mathrm{H}_{24}$ & Sesquiterpenes & 6.41 & 0.87 & - & - & - & - \\
\hline$\beta$-Cubebene & $\mathrm{C}_{20} \mathrm{H}_{18} \mathrm{O}_{6}$ & Sesquiterpenes & 6.51 & 1.37 & 6.55 & 2.44 & 6.5 & 5.49 \\
\hline$\alpha$-Cadinene & $\mathrm{C}_{15} \mathrm{H}_{24}$ & Sesquiterpenes & 7 & 0.79 & 7.01 & 0.8 & 7.06 & 0.94 \\
\hline$\delta$-Cadinene & $\mathrm{C}_{15} \mathrm{H}_{24}$ & Sesquiterpenes & 7.13 & 1.52 & - & - & - & - \\
\hline Caryophyllene oxide & $\mathrm{C}_{15} \mathrm{H}_{24} \mathrm{O}$ & Sesquiterpenes & 8.15 & 2.22 & 8.15 & 3.11 & 8.12 & I.II \\
\hline$\alpha$-Cadinol & $\mathrm{C}_{15} \mathrm{H}_{26}$ & Sesquiterpenes & 9.28 & 3.47 & - & - & - & - \\
\hline $\begin{array}{l}\text { I7-hydroxy-I7-methyl-(I7 } \alpha) \text { - } \\
\text { androsta-I,4-dien-3-one }\end{array}$ & $\mathrm{C}_{19} \mathrm{H}_{26} \mathrm{O}_{2}$ & Di-terpenes & 12.06 & 2.03 & - & - & - & - \\
\hline Aromadendrene oxide-(2) & $\mathrm{C}_{15} \mathrm{H}_{24} \mathrm{O}$ & Sesquiterpenes & 12.62 & 1.15 & - & - & - & - \\
\hline Cembrene & $\mathrm{C}_{20} \mathrm{H}_{32}$ & Di-terpenes & 13.8 & 1.56 & 13.83 & 5.8 & 13.8 & 5.29 \\
\hline $\begin{array}{l}\text { I-(+)-Ascorbic acid } \\
\text { 2,6-dihexadecanoate }\end{array}$ & $\mathrm{C}_{38} \mathrm{H}_{68} \mathrm{O}_{8}$ & Hydrocarbons & 14.17 & 3 & - & - & - & - \\
\hline Dibutyl phthalate & $\mathrm{C}_{16} \mathrm{H}_{22} \mathrm{O}_{4}$ & Phthalates & 14.22 & 2.54 & 14.23 & I & 14.27 & 0.92 \\
\hline $\begin{array}{l}\text { 3,7, II-Trimethyl } \\
-\mid 4-(I-\text { methylet hyl)- } \\
{[S-(E, Z, E, E)]-I, 3,6, I 0-} \\
\text { cyclotetradecatetraene }\end{array}$ & $\mathrm{C}_{15} \mathrm{H}_{26} \mathrm{O}$ & Hydrocarbons & 15.69 & 2.3 & 15.69 & 14.29 & 15.68 & 15.84 \\
\hline Thunbergol & $\mathrm{C}_{20} \mathrm{H}_{34} \mathrm{O}$ & Di-terpenes & 15.88 & 4.64 & 15.88 & 30.71 & 15.87 & 19.46 \\
\hline Phytol & $\mathrm{C}_{20} \mathrm{H}_{40} \mathrm{O}$ & $\begin{array}{l}\text { acyclic di-terpene } \\
\text { alcohol }\end{array}$ & 16.54 & 1.94 & - & - & - & - \\
\hline Linolenic acid & $\mathrm{C}_{18} \mathrm{H}_{30} \mathrm{O}_{2}$ & Fatty acids & 16.89 & 2.95 & - & - & - & - \\
\hline
\end{tabular}


Table Continued.

\begin{tabular}{|c|c|c|c|c|c|c|c|c|}
\hline \multirow{3}{*}{ Compound name } & \multirow{3}{*}{$\begin{array}{l}\text { Molecular } \\
\text { formula }\end{array}$} & \multirow{3}{*}{ Chemical class } & \multicolumn{6}{|c|}{ Altitude (m) } \\
\hline & & & \multicolumn{2}{|l|}{ I (I $25 \mathrm{~m})$} & \multicolumn{2}{|c|}{ II (39I m) } & \multicolumn{2}{|c|}{ III (85I m) } \\
\hline & & & Rt (min) & $\begin{array}{l}\text { Area } \\
(\%)\end{array}$ & Rt (min) & $\begin{array}{l}\text { Area } \\
(\%)\end{array}$ & $\begin{array}{l}\text { Rt } \\
\text { (min) }\end{array}$ & $\begin{array}{l}\text { Area } \\
\text { (\%) }\end{array}$ \\
\hline Sclareol & $\mathrm{C}_{20} \mathrm{H}_{36} \mathrm{O}_{2}$ & Di-terpenoids & 18.37 & 3.78 & 18.37 & 9.76 & 18.36 & 6.21 \\
\hline Androstenediol & $\mathrm{C}_{19} \mathrm{H}_{30} \mathrm{O}_{2}$ & Steroids & - & - & - & - & 18.84 & $|.5|$ \\
\hline Totarol & $\mathrm{C}_{20} \mathrm{H}_{30} \mathrm{O}$ & Terpenophenolics & - & - & - & - & 19.38 & 3.1 \\
\hline Anticopalic acid & $\mathrm{C}_{20} \mathrm{H}_{32} \mathrm{O}_{2}$ & Di-terpenes & 19.88 & 3.04 & 19.89 & 19.2 & 19.94 & 11.79 \\
\hline Mono(2-ethylhexyl) phthalate & $\mathrm{C}_{16} \mathrm{H}_{22} \mathrm{O}_{4}$ & Phthalates & 20.07 & 3.32 & - & - & - & - \\
\hline Retinol & $\mathrm{C}_{20} \mathrm{H}_{30} \mathrm{O}$ & Retinol & - & - & - & - & 20.28 & 1.8 \\
\hline Retinoic acid methyl ester & $\mathrm{C}_{21} \mathrm{H}_{30} \mathrm{O}_{2}$ & Retinol & 20.79 & 2.04 & 20.8 & 3 & 20.81 & 9.65 \\
\hline Dehydroabietal & $\mathrm{C}_{20} \mathrm{H}_{28} \mathrm{O}$ & Di-terpenes & 21.11 & 5.6 & - & - & - & - \\
\hline I-Heptatriacotanol & $\mathrm{C}_{37} \mathrm{H}_{76} \mathrm{O}$ & Hydrocarbons & 21.69 & 9.28 & - & - & - & - \\
\hline Methyl retinoate & $\mathrm{C}_{21} \mathrm{H}_{30} \mathrm{O}_{2}$ & Retinol & 21.96 & 0.87 & 21.96 & I & 21.96 & 1.39 \\
\hline$\alpha$-Pimaric acid & $\mathrm{C}_{20} \mathrm{H}_{30} \mathrm{O}_{2}$ & Resin acids & 22.43 & 0.77 & - & - & - & - \\
\hline Di-n-octyl phthalate & $\mathrm{C}_{24} \mathrm{H}_{38} \mathrm{O}_{4}$ & Phthalates & 22.52 & 4.07 & 22.52 & 2.07 & 22.52 & 0.85 \\
\hline Androsterone & $\mathrm{C}_{19} \mathrm{H}_{30} \mathrm{O}_{2}$ & Steroids & 22.67 & 2.61 & - & - & - & - \\
\hline Obacunone & $\mathrm{C}_{26} \mathrm{H}_{30} \mathrm{O}_{7}$ & Triterpenoids & 22.79 & 0.7 & 22.79 & 0.73 & 22.8 & 0.98 \\
\hline Androstadienedione & $\mathrm{C}_{19} \mathrm{H}_{24} \mathrm{O}_{2}$ & Steroids & 23.15 & 1.59 & - & - & - & - \\
\hline I-Heptatriacotanol & $\mathrm{C}_{37} \mathrm{H}_{76} \mathrm{O}$ & Hydrocarbons & 23.29 & 1.64 & - & - & - & - \\
\hline I7-Pentatriacontene & $\mathrm{C}_{35} \mathrm{H}_{70}$ & Hydrocarbons & 28.93 & 0.89 & - & - & - & - \\
\hline$\alpha$-Sitosterol & $\mathrm{C}_{29} \mathrm{H}_{50} \mathrm{O}$ & Steroids & 31.15 & 1.68 & - & - & - & - \\
\hline Total peak area (\%) & & & $93.34 \%$ & & $100.00 \%$ & & $97.00 \%$ & \\
\hline
\end{tabular}

Table 3 Chemical composition and main constituents of the crud extracts isolated from bark of P. halepensis at different altitudes in AL-Jabal AL-Akhdar region by $\mathrm{GC} / \mathrm{MS}$ analysis

\begin{tabular}{|c|c|c|c|c|c|c|c|c|}
\hline \multirow{3}{*}{ Compound name } & \multirow{3}{*}{$\begin{array}{l}\text { Molecular } \\
\text { formula }\end{array}$} & \multirow{3}{*}{ Chemical class } & \multicolumn{6}{|c|}{ Altitude (m) } \\
\hline & & & \multicolumn{2}{|l|}{ I (I $25 \mathrm{~m})$} & \multicolumn{2}{|c|}{ II (39I m) } & \multicolumn{2}{|c|}{ III (85 I m) } \\
\hline & & & Rt (min) & $\begin{array}{l}\text { Area } \\
(\%)\end{array}$ & Rt (min) & $\begin{array}{l}\text { Area } \\
(\%)\end{array}$ & $\begin{array}{l}\text { Rt } \\
\text { (min) }\end{array}$ & $\begin{array}{l}\text { Area } \\
(\%)\end{array}$ \\
\hline L-3,4-dihydroxyphenylalanine & $\mathrm{C}_{9} \mathrm{H}_{11} \mathrm{NO}_{4}$ & Amino acids & 8.2 & 12.33 & - & - & - & - \\
\hline D-glucose, 4,6-o-ethylidene & $\mathrm{C}_{8} \mathrm{H}_{14} \mathrm{O}_{6}$ & Sugars & 8.74 & 40.19 & 8.68 & 50.4 & 8.69 & 17.68 \\
\hline $\begin{array}{l}\text { I-(+)-Ascorbic acid } \\
\text { 2,6-dihexadecanoate }\end{array}$ & $\mathrm{C}_{38} \mathrm{H}_{68} \mathrm{O}_{8}$ & Hydrocarbons & - & - & - & - & 14.19 & 14.52 \\
\hline Dibutyl phthalate & $\mathrm{C}_{16} \mathrm{H}_{22} \mathrm{O}_{4}$ & Phthalates & $|4.2|$ & 10.88 & 14.2 & 14 & 14.53 & 2.95 \\
\hline $\begin{array}{l}\text { 2,2'-dimethyl-6,6'-dinitro-I, I'- } \\
\text { Biphenyl }\end{array}$ & $\mathrm{C}_{14} \mathrm{H}_{12} \mathrm{~N}_{2} \mathrm{O}_{6}$ & Biphenyls & - & - & - & - & 19.22 & 2.12 \\
\hline 5,8, II, I4-Eicosatetraynoic acid & $\mathrm{C}_{20} \mathrm{H}_{24} \mathrm{O}_{2}$ & Diterpenes & 19.83 & 4.99 & - & - & - & - \\
\hline Di-n-octyl phthalate & $\mathrm{C}_{24} \mathrm{H}_{38} \mathrm{O}_{4}$ & Phthalates & 22.51 & 13.04 & 22.51 & 13.1 & 22.51 & 24.56 \\
\hline $\begin{array}{l}\text { 2,2'-Methylenebis(5-methyl-6- } \\
\text { tert-butylphenol) }\end{array}$ & $\mathrm{C}_{23} \mathrm{H}_{32} \mathrm{O}_{2}$ & $\begin{array}{l}\text { Chlorinated } \\
\text { hydrocarbons }\end{array}$ & - & - & - & - & 29.54 & 2.87 \\
\hline Lycophyll & $\mathrm{C}_{40} \mathrm{H}_{56} \mathrm{O}_{2}$ & Carotenoids & - & - & - & - & 30.21 & 3.22 \\
\hline$\beta$-Sitosterol & $\mathrm{C}_{29} \mathrm{H}_{50} \mathrm{O}$ & Sterols & 31.15 & 18.57 & 31.14 & 22.5 & 31.14 & 32.08 \\
\hline Total peak area (\%) & & & $100.00 \%$ & & $100.00 \%$ & & $100.00 \%$ & \\
\hline
\end{tabular}




\section{Chemical composition of crude extracts of 0 . europea}

The data in Tables 4 and 5 represent the identified compounds with their retention times and peak area. In total, 5, 8 and 10 different components, representing $100 \%$ of the total extracts at three different altitudes $(125,391$ and $851 \mathrm{~m}$, respectively) were detected in $O$. Europea (Table 4). However, extracts of crud from the bark led to the identification of 13,16 and 15 compounds, representing 97.55, 99.70 and $98.05 \%$ of the total extract at three different altitudes respectively (Table 5). The major components detected in leaf extracts of altitudes I, II and III (Table 4) were 3,4-dihydroxy-benzeneacetic acid $(57.65,18.26$, and 5.31\%), methyl elaidate $(8.38,9.20$, and $18.67 \%)$, and di-n-octyl phthalate $(12.73,7.83$, and $15.86 \%)$. It can be noted that the compound of 3,4-dihydroxy-benzeneacetic acid was gradually increase in their percentages with increase the level of altitude. Acetic acid, 1,7,7-trimethyl-bicyclo[2.2.1] hept-2-yl ester was only detected in extract of tree at altitude I with high abundance of $18.68 \%$ of total weight however, tyrosol was only detected in extracts of tree at altitudes I and II with 2.38 and $1.45 \%$, respectively. The compounds include betulin, astaxanthin, oleanolic acid and taraxosterate were found in the two extracts obtained from the leaves at altitudes II and III with abundance ranging from 1.80 to $33.61 \%$ of the total weight. Other compounds, including oxiraneoctanoic acid, phytol and totarol, appeared only in altitude extract III with 4.99, 8.30 and $6.23 \%$, respectively. The chemical classes of the detected compounds of leaf extracts confirmed that these extracts contain a complex mixture composed of phenylethanoid, sesquiterpene hydrocarbons, diterpene hydrocarbons, diterpenoids, terpenophenols, triterpenes and tetroperes (Table 4). The result of the chemical composition of the acetone extracts obtained from the O. Europea (Table 5) showed that the compounds of totarol, gibelomeric acid, bis-ethylhexyl hydroxydimethoxy benzylmalonate, betulin and $\beta$-sitosterol were found in leaf extracts of altitudes I, II and III and progressively increased in percentage with the increase in altitude level. However, tyrosol, 3,4-dihydroxy-benzeneacetic acid, methyl elaidate, dibutyl phthalate, oleic acid, and di-n-octyl phthalate, DNPL-arginine were gradually decreased in leaf extracts of altitudes I, II and III. Compounds of (2-phenyl-1,3-dioxolan-4-yl)methyl (9E)9-octadecenoate, digoxigenin, and pregn-4-ene-3,20-dione,17,21dihydroxy-,bis(O-methyloxime) were found in both extracts obtained from leaves at altitudes II and III with abundance ranged from 1.80 to $33.61 \%$ of total weight and disappeared from altitude I. The chemical classes of the detected compounds of bark extracts confirmed that these extracts contained a complex mixture consisting of Phenylethanoid, amino acids, fatty acids, diterpene hydrocarbons, sesquiterpenes, triterpenes, terpenophenolics, phthalates, hormones, and steroids. It was observed that ingested olive leaf extract was effectively to deliver oleuropein and hydroxytrosol metabolites to plasma in humans. ${ }^{63}$ Seven phenolic compounds: caffeic acid, verbascoside, oleuropein, luteolin 7-O-glucoside, rutin, apigenin 7-O-glucoside and luteolin 4'-O-glucoside were found in O. europaea leaf aqueous extract. ${ }^{19}$ Tyrosol, similar to our findings were found both extract leaves and bark. ${ }^{64}$ Keskin et al. ${ }^{65}$ reported the GC/MS analysis revealed that the major constituents of the olive leaves extract were cyclotrisiloxane hexamethyl (36.98\%), cyclotetrasiloxane octamethyl $(15.18 \%)$ and cyclopentasiloxane decamethyl $(14.59 \%)$. Tyrosol, hydroxy tyrosol and cinnamic acid derivatives were reported in olive leaves and may cause antimicrobial activity from. ${ }^{65}$ Recently, phenolic composition with tannin contents and their biological activities of fruit extracts from Italian and Algerian Olea europaea L. cultivars were studied. ${ }^{40}$ Fourteen different phenolic compounds including hydroxytyrosol, tyrosol, p-hydroxybenzoic acid, and verbascoside as major constituents were identified, and their profiles showed remarkable quantitative differences among analyzed extracts. The authors reported that there were no significant qualitative differences among samples, but it is possible to note important quantitative differences.

Table 4 Chemical composition and main constituents of the crud extracts isolated from $O$. europaea leaves at different altitudes in AL-Jabal AL-Akhdar region by GC/MS analysis

\begin{tabular}{|c|c|c|c|c|c|c|c|c|}
\hline \multirow{3}{*}{ Compound name } & \multirow{3}{*}{$\begin{array}{l}\text { Molecular } \\
\text { formula }\end{array}$} & \multirow{3}{*}{ Chemical class } & \multicolumn{6}{|c|}{ Altitude (m) } \\
\hline & & & \multicolumn{2}{|c|}{ I (I $25 \mathrm{~m})$} & \multicolumn{2}{|c|}{ II (39l m) } & \multicolumn{2}{|c|}{ III (85 I m) } \\
\hline & & & $\begin{array}{l}\text { Rt } \\
(\mathbf{m i n})\end{array}$ & $\begin{array}{l}\text { Area } \\
(\%)\end{array}$ & $\begin{array}{l}\text { Rt } \\
(\min )\end{array}$ & $\begin{array}{l}\text { Area } \\
(\%)\end{array}$ & $\begin{array}{l}\text { Rt } \\
(\min )\end{array}$ & $\begin{array}{l}\text { Area } \\
(\%)\end{array}$ \\
\hline Tyrosol & $\mathrm{C}_{8} \mathrm{H}_{10} \mathrm{O}$ & Phenylethanoid & 5.38 & 2.38 & 5.38 & 1.45 & - & - \\
\hline $\begin{array}{l}\text { Oxiraneoctanoic acid, 3-octyl-, } \\
\text { cis- }\end{array}$ & $\mathrm{C}_{18} \mathrm{H}_{34} \mathrm{O}_{3}$ & $\begin{array}{l}\text { Sesquiterpene } \\
\text { hydrocarbons }\end{array}$ & - & - & - & - & 8.11 & 4.99 \\
\hline $\begin{array}{l}\text { 3,4-Dihydroxy-benzeneacetic } \\
\text { acid }\end{array}$ & $\mathrm{C}_{8} \mathrm{H}_{8} \mathrm{O}_{4}$ & Hydrocarbons & 9.03 & 57.65 & 9.01 & 18.26 & 9.01 & 5.31 \\
\hline Methyl elaidate & $\mathrm{C}_{19} \mathrm{H}_{36} \mathrm{O}_{2}$ & $\begin{array}{l}\text { Diterpene } \\
\text { hydrocarbons }\end{array}$ & 11.41 & 8.38 & 11.41 & 9.2 & $\mid 1.41$ & 18.67 \\
\hline $\begin{array}{l}\text { Acetic acid, I,7,7-trimethyl- } \\
\text { bicyclo[2.2. I] }\end{array}$ & $\mathrm{C}_{12} \mathrm{H}_{20} \mathrm{O}_{2}$ & $\begin{array}{l}\text { Monoterpene } \\
\text { ydrocarbons }\end{array}$ & 12.16 & 18.86 & - & - & - & - \\
\hline Phytol & $\mathrm{C}_{20} \mathrm{H}_{40} \mathrm{O}$ & $\begin{array}{l}\text { acyclic diterpene } \\
\text { alcohol }\end{array}$ & - & - & - & - & $16.5 \mid$ & 8.3 \\
\hline Totarol & $\mathrm{C}_{20} \mathrm{H}_{30} \mathrm{O}$ & Terpenophenolics & - & - & - & - & 19.38 & 6.23 \\
\hline Di-n-octyl phthalate & $\mathrm{C}_{24} \mathrm{H}_{38} \mathrm{O}_{4}$ & Phthalates & 22.51 & 12.73 & 22.51 & 7.83 & 22.51 & 15.86 \\
\hline Betulin & $\mathrm{C}_{30} \mathrm{H}_{50} \mathrm{O}_{2}$ & Triterpenes & - & - & 29.47 & 33.61 & 29.47 & 11.03 \\
\hline Astaxanthin & $\mathrm{C}_{40} \mathrm{H}_{52} \mathrm{O}_{4}$ & Tetraterpenoids & - & - & 30.53 & 26 & 30.54 & 16 \\
\hline
\end{tabular}


Table Continued.

\begin{tabular}{|c|c|c|c|c|c|c|c|c|}
\hline \multirow{3}{*}{ Compound name } & \multirow{3}{*}{$\begin{array}{l}\text { Molecular } \\
\text { formula }\end{array}$} & \multirow{3}{*}{ Chemical class } & \multicolumn{6}{|c|}{ Altitude (m) } \\
\hline & & & \multicolumn{2}{|c|}{ I (I $25 \mathrm{~m})$} & \multicolumn{2}{|c|}{ II (39I m) } & \multicolumn{2}{|c|}{ III (85I m) } \\
\hline & & & $\begin{array}{l}\text { Rt } \\
(\mathbf{m i n})\end{array}$ & $\begin{array}{l}\text { Area } \\
\text { (\%) }\end{array}$ & $\begin{array}{l}\text { Rt } \\
(\min )\end{array}$ & $\begin{array}{l}\text { Area } \\
\text { (\%) }\end{array}$ & $\begin{array}{l}\text { Rt } \\
(\mathbf{m i n})\end{array}$ & $\begin{array}{l}\text { Area } \\
\text { (\%) }\end{array}$ \\
\hline Oleanolic acid & $\mathrm{C}_{30} \mathrm{H}_{48} \mathrm{O}_{3}$ & Triterpenoids & - & - & 31.51 & 1.8 & 31.5 & 7.65 \\
\hline Taraxasterol & $\mathrm{C}_{30} \mathrm{H}_{50} \mathrm{O}$ & Triterpenoids & - & - & 32 & 1.85 & 32 & 5.96 \\
\hline Total peak area (\%) & & & $100.00 \%$ & & $100.00 \%$ & & $100.00 \%$ & \\
\hline
\end{tabular}

Table 5 Chemical composition and main constituents of the crud extracts isolated from bark of O. europaea at different altitudes in AL-Jabal AL-Akhdar region by $\mathrm{GC} / \mathrm{MS}$ analysis

\begin{tabular}{|c|c|c|c|c|c|c|c|c|}
\hline \multirow{3}{*}{ Compound Name } & \multirow{3}{*}{$\begin{array}{l}\text { Molecular } \\
\text { formula }\end{array}$} & \multirow{3}{*}{ Chemical class } & \multicolumn{6}{|c|}{ Altitude (m) } \\
\hline & & & \multicolumn{2}{|l|}{ I ( $125 \mathrm{~m})$} & \multicolumn{2}{|c|}{ II (39l m) } & \multicolumn{2}{|c|}{ III (85 I m) } \\
\hline & & & Rt (min) & $\begin{array}{l}\text { Area } \\
(\%)\end{array}$ & $\begin{array}{l}\text { Rt } \\
\text { (min) }\end{array}$ & $\begin{array}{l}\text { Area } \\
(\%)\end{array}$ & Rt (min) & $\begin{array}{l}\text { Area } \\
(\%)\end{array}$ \\
\hline Tyrosol & $\mathrm{C}_{8} \mathrm{H}_{10} \mathrm{O}$ & Phenylethanoid & 5.38 & 2.24 & 5.38 & 2.18 & 5.38 & 1.81 \\
\hline $\begin{array}{l}\text { 3,4-Dihydroxy-benzeneacetic } \\
\text { acid }\end{array}$ & $\mathrm{C}_{8} \mathrm{H}_{8} \mathrm{O}_{4}$ & Hydrocarbons & 9.04 & 34.44 & 9.02 & 24.86 & 9.02 & 16.21 \\
\hline $\begin{array}{l}\text { (2-Phenyl-I,3-dioxolan-4-yl) } \\
\text { methyl (9E)-9-octadecenoate }\end{array}$ & $\mathrm{C}_{28} \mathrm{H}_{44}$ & Hydrocarbons & - & - & 9.55 & 1.97 & 9.55 & 2.4 \\
\hline Methyl elaidate & $\mathrm{C}_{19} \mathrm{H}_{36} \mathrm{O}_{2}$ & Diterpene hydrocarbons & $11.4 \mid$ & 5.88 & $\mathrm{II} .4$ & 5.81 & $1 \mathrm{I} .4 \mathrm{I}$ & 5.74 \\
\hline Widdrol hydroxyether & $\mathrm{C}_{15} \mathrm{H}_{26} \mathrm{O}_{2}$ & Sesquiterpenes & 14.08 & 3.74 & 14.08 & 1.96 & - & - \\
\hline Dibutyl phthalate & $\mathrm{C}_{16} \mathrm{H}_{22} \mathrm{O}_{4}$ & Phthalates & 14.19 & 1.85 & 14.19 & 1.61 & 14.19 & 1.13 \\
\hline Oleic Acid & $\mathrm{C}_{18} \mathrm{H}_{34}$ & Fatty acids & 16.85 & 2.26 & 16.85 & 2.08 & 16.85 & 1.7 \\
\hline Totarol & $\mathrm{C}_{20} \mathrm{H}_{30} \mathrm{O}$ & Terpenophenolics & 19.37 & 3.03 & 19.37 & 3.78 & 19.37 & 4.42 \\
\hline Di-n-octyl phthalate & $\mathrm{C}_{24} \mathrm{H}_{38} \mathrm{O}_{4}$ & Phthalates & 22.5 & 3.25 & 22.5 & 2.98 & 22.5 & 1.99 \\
\hline DNP-L-arginine & $\mathrm{C}_{12} \mathrm{H}_{16}$ & Amino acids & 25.93 & 8.78 & 25.89 & 8.7 & 25.88 & 8.38 \\
\hline Gibberellic acid & $\mathrm{C}_{19} \mathrm{H}_{22}$ & Hormones & 26.43 & 6.57 & 26.4 & 7.97 & 26.42 & 10.53 \\
\hline $\begin{array}{l}\text { bis-ethylhexyl hydroxydimethoxy } \\
\text { benzylmalonate }\end{array}$ & $\mathrm{C}_{28} \mathrm{H}_{46} \mathrm{O}_{7}$ & Diterpene hydrocarbons & 26.78 & 18.38 & 26.75 & 19.88 & 26.77 & 23.07 \\
\hline Astaxanthin & $\mathrm{C}_{40} \mathrm{H}_{52} \mathrm{O}_{4}$ & Tetraterpenoids & 30.64 & 4.87 & 30.63 & 5.03 & 30.64 & 6.04 \\
\hline Digoxigenin & $\mathrm{C}_{23} \mathrm{H}_{34} \mathrm{O}_{5}$ & Steroids & - & - & 30.77 & 6.18 & 30.77 & 8.54 \\
\hline $\begin{array}{l}\text { Pregn-4-ene-3,20-dione, I7,2I- } \\
\text { dihydroxy-,bis(O-methyloxime) }\end{array}$ & $\mathrm{C}_{23} \mathrm{H}_{36} \mathrm{~N}_{2} \mathrm{O}_{4}$ & Diterpene hydrocarbons & - & - & 30.93 & 1.34 & 30.94 & 1.89 \\
\hline$\beta$-Sitosterol & $\mathrm{C}_{29} \mathrm{H}_{50} \mathrm{O}$ & Sterols & 31.14 & 2.26 & 31.41 & 3.37 & 31.14 & 4.2 \\
\hline Total peak area (\%) & & & $97.55 \%$ & & $99.70 \%$ & & $98.05 \%$ & \\
\hline
\end{tabular}

\section{Antibacterial activity}

The antibacterial activity (MIC values in $\mathrm{mg} / \mathrm{L}$ ) of acetone extracts from bark and leaves of $P$. halepensis and $O$. europaea trees against $A$. tumefaciens, E. carotovora, C. fascians and $P$. solanacearum is shown in Table 6. Generally, all extracts exhibited promising antibacterial potency with varying degrees of inhibition with MIC values ranging from 480 to $1300 \mathrm{mg} / \mathrm{L}$. Among all the extracts obtained from the three altitudes of the studied trees, the best MICs values observed were $525,530,410$, and $645 \mathrm{mg} / \mathrm{L}$ against the growth of $A$. tumefaciens, E. carotovora, $C$. fascians and $P$. solanacearum, respectively for the extract from $O$. europaea at altitude I followed by the leaf extract
$(\mathrm{MIC}=545,650,480$, and $700 \mathrm{mg} / \mathrm{L}$, respectively) for $O$. europaea at the same level of altitude $(125 \mathrm{~m})$. It is noted that the extracts obtained from barks and leaves of $O$. europaea at three altitudes showed that antibacterial activity decreased with increasing altitude. The extract obtained from the $P$. halepensis needles showed that Level I extract was the most active of the three levels of altitude with MIC values of $600,840,585$ and $900 \mathrm{mg} / \mathrm{L}$ against the growth of $A$. tumefaciens, $E$. carotovora, C. fascians and P. solanacearum, respectively. However, the level II extract showed the lowest activity with MIC of 735, 1200,850 and $1300 \mathrm{mg} / \mathrm{L}$ against the same bacteria, respectively. On the other hand, the extract obtained from the bark indicated that the altitude extract III was the most active among the three altitude 
levels (MIC=555, 600, 610 and $835 \mathrm{mg} / \mathrm{L}$ against $A$. tumefaciens, $E$. carotovora, C. fascians and P. solanacearum, respectively). Several studies of extracts derived from the aerial parts of $P$. halepensis and $O$. europaea have shown that it has good antibacterial activity and that the activity of plant extracts is mainly attributed to the presence of phenolic compounds, alkaloids, flavonoids, terpenoids and other essential phytochemicals. ${ }^{32,36,66-72}$ The aqueous extract of $O$. europaea leaves showed good activity against Escherichia coli with MIC of $150 \mu \mathrm{L} / \mathrm{mL}$ and inhibition zone of $15.3 \mathrm{~mm}$ in diameter. ${ }^{24}$ Keskin et al. ${ }^{65}$ reported that aqueous extract of olive leaves show antimicrobial activity against opportunistic pathogens like met-oxa res $S$. aureus, $P$. aeruginosa, E. coli and K. pneumonia. ${ }^{65}$ Korukluoglu et al. ${ }^{73}$ reported that water extract of olive leaves did not show any inhibition effects on all the tested bacteria, but Gumgumjee et al. ${ }^{74}$ showed that $O$. europaea leaf extract had higher activity against tested organisms than the stems. In addition, Aliabadi and others reported that $O$. europaea extracts did not present broad-spectrum antibacterial activity, ${ }^{75}$ but was found to be most active against Campylobacter jejuni, Helicobacter pylori and S. aureus with MICs as low as $0.31-0.78 \%(\mathrm{v} / \mathrm{v}){ }^{22}$

Markin et al. ${ }^{76}$ reported that olive leaf extract with a concentration of $0.6 \%(\mathrm{w} / \mathrm{v})$ killed E. coli, P. aeruginosa, S. aureus and K.pneumonia in $3 \mathrm{~h}$ exposure, and on the other hand inhibited $B$. subtilis only when the concentration was increased to $20 \%(\mathrm{w} / \mathrm{v})$ which may be due to the ability to form spores of this species. ${ }^{76}$ Olive leaf extracts showed good inhibitory effects on pathogenic bacteria and fungi and all the extracts were a higher activity showed good inhibitory effects toward E. coli and B. cereus, which could be related to a higher yield of flavonoids. ${ }^{54,75}$ Korukluoglu et al..$^{20}$ studied the effect of the different solvent extraction on the bioactivity of olive leaf extract against some bacterial pathogens, and the results showed that the solvent type affected the distribution of phenolic and concentration in extracts. They reported that ethanol extract of $O$. europaea leaves showed the highest antimicrobial efficiency against $E$. coli and $S$. enteritidis, while, acetone extracts showed the activity against $S$. thypimurium. ${ }^{73}$ However, acetone leaf extract of $O$. europaea showed Inhibition concentration of $55 \mu \mathrm{g} / \mathrm{mL}$ against $S$. aureus, $60 \mu \mathrm{g} / \mathrm{mL}$ with Escherichia coli, $110 \mu \mathrm{g} / \mathrm{mL}$ against S. typhimurium, and 170 $\mu \mathrm{g} / \mathrm{mL}$ against $S$. enteritidis. ${ }^{20}$ Additionally, phenolic compounds within olive leaf extract have shown antimicrobial activities against several microorganisms including: E. coli, S. aureus, K. pneumoniae, B. cereus, $S$. typhi and $V$. parahaemolyticu. ${ }^{64}$ Oleuropein, the main glycoside present in olives, has been shown to have strong antimicrobial activity against both Gram-negative and Gram-positive bacteria. ${ }^{77}$ In addition, hydroxytyrosol and oleuropein have been proven to inhibit orderly the rate of growth of several human intestinal or respiratory tract pathogens. ${ }^{54}$

\section{Antifungal activity}

The in vitro antifungal activity of the extracts obtained from bark and leaves of $P$. halepensis and $O$. europaea with different altitudes is presented in Table 7 as $\mathrm{EC}_{50}$ values in $\mathrm{mg} / \mathrm{L}$ with their statistical parameters. The results showed all extracts exhibited a significant antifungal potency with varying degrees of inhibition of growth with $\mathrm{EC}_{50}$ values ranging from 71.10 to $154.71 \mathrm{mg} / \mathrm{L}$. Leaf extracts of $O$. europaea at altitude II showed the highest effect with $\mathrm{EC}_{50}$ of $71.10 \mathrm{mg} / \mathrm{L}$ followed by the bark extract from altitude III $\left(\mathrm{EC}_{50}=89.55 \mathrm{mg} / \mathrm{L}\right)$. As can be seen that the extracts from bark and leaves of $O$. europaea showed higher antifungal activity than extracts of bark and leaves of $P$. halepensis. On the other hand, the extracts obtained from the leaves of $P$. halepensis had higher activity $\left(\mathrm{EC}_{50}=119.20,134.20\right.$, and $115.42 \mathrm{mg} / \mathrm{L})$ than the bark extracts $(127.30,154.71$, and $139.70 \mathrm{mg} / \mathrm{L})$ at altitudes I, II, and III, respectively. It can be noted that the bark extracts of altitude I were the most powerful followed by altitude III then the extract of altitude II. However, the leaf extract of altitude III was the most powerful followed by altitude, then the extract of altitude II. This result is explained by the chemical composition of the extracts, as shown in Table 2, which indicates that the GC/MS analyzes of the acetone extracts of the $P$. halepensis needles identified 38, 15 and 18 different components To three different altitudes $(125,391$ and $851 \mathrm{~m}$, respectively). The antimicrobial activity of plant extracts might not be due to the action of a single active compound, but the synergistic effect of several compounds that are in minor proportion in a plant. ${ }^{39,78-80}$ Although the individual phenolic compounds in olive extract may show strong in vitro activities, antioxidant and antimicrobial activities of combined phenolics showed similar or better effects than the individual phenolics. ${ }^{18,54,64,81,82}$ For example, the crude $\mathrm{MeOH}$ extract as well as some compounds isolated from stem bark of Vismia rubescens showed both antifungal and antibacterial activities, while some compounds isolated showed only antibacterial activity (MIC $=12.5-200 \mathrm{~g} / \mathrm{ml}$ ) and no antifungal activity. ${ }^{83}$ Faiza et al..$^{54}$ confirmed that the extracts may be more beneficial than isolated constituents since a bioactive component can change its properties in the presence of other compounds present in the extract. ${ }^{54}$ They also reported the antifungal capacity order for several concentrations of olive leaf and olive extracts against Candida albicans and $C$. neoformans. The inhibitory activity of crude extracts isolated from $P$. halepensis and O.europaea against $B$. cinerea in this study was higher than reported by Abdelgaleil et al. ${ }^{84}$ who observed the five sesquiterpenes compounds isolated from Ambrosia maritima were shown $\mathrm{EC}_{50}$ ranged between $316.6-495.3 \mathrm{mg} / \mathrm{L}$ on $B$. cinerea ${ }^{84}$ Results of biological assays with crude extracts of leaf and bark extracts against $B$. cinerea could be related to the high percentage of chemical composition. These results are in agreement with those of other essential oils which showed the largest inhibition zone $18.3 \pm 0.6$ in the presence of essential oil of fraction T6 from branches while none Effect of root essential oils against $B$. cinerea ${ }^{85}$ In study by Tamokou et al. ${ }^{83}$ evaluated the antibacterial and antifungal activities of the crude extract and the isolated compounds. ${ }^{83}$ The results showed that the crude extract prevented the growth of all microorganisms tested. The crude methanolic extract as well as some isolated compounds showed antifungal and antibacterial activities. Although some compounds have only antibacterial activities (MIC=12.5-200mg/L) and no antifungal activity.

Table 6 Antibacterial activity of crude extracts isolated from bark and leaves of $P$. halepensis and $O$. europaea trees grown at the three levels of altitude in Al-Jabal Al-Akhdar (Libya) against A. tumefaciens, E. carotovora, C. fascians and P. solanacearum

\begin{tabular}{|c|c|c|c|c|c|}
\hline \multirow{2}{*}{ Extracts } & \multirow{2}{*}{ Altitude } & \multicolumn{4}{|l|}{ MIC (mg/L) } \\
\hline & & A. tumefaciens & E. carotovora & C. fascians & P. solanacearum \\
\hline \multirow{3}{*}{ P. halepensis bark } & $\mathrm{I}(\mathrm{I} 25 \mathrm{~m})$ & 695 & 790 & 750 & 940 \\
\hline & $\|(39 m)$ & 630 & 720 & 665 & 850 \\
\hline & $\mathrm{III}(85 \mathrm{Im})$ & 555 & 600 & 610 & 835 \\
\hline
\end{tabular}


Table Continued...

\begin{tabular}{|c|c|c|c|c|c|}
\hline \multirow{2}{*}{ Extracts } & \multirow{2}{*}{ Altitude } & \multicolumn{4}{|l|}{ MIC (mg/L) } \\
\hline & & A. tumefaciens & E. carotovora & C. fascians & P. solanacearum \\
\hline \multirow{3}{*}{ P. halepensis leaf } & $\mathrm{I}(\mathrm{I} 25 \mathrm{~m})$ & 600 & 840 & 585 & 900 \\
\hline & $\|(39 m)$ & 735 & 1200 & 850 & 1300 \\
\hline & $\mathrm{III}(85 \mathrm{Im})$ & 675 & 940 & 730 & 1050 \\
\hline \multirow{3}{*}{ O. europaea bark } & $\mathrm{I}(\mathrm{I} 25 \mathrm{~m})$ & 525 & 530 & 410 & 645 \\
\hline & II(39Im) & 665 & 680 & 640 & 840 \\
\hline & $\mathrm{III}(85 \mathrm{Im})$ & 810 & 830 & 670 & 930 \\
\hline \multirow{3}{*}{ O. europaea leaf } & $\mathrm{I}(\mathrm{I} 25 \mathrm{~m})$ & 545 & 650 & 480 & 700 \\
\hline & II(39Im) & 775 & 780 & 580 & 720 \\
\hline & III(85Im) & 910 & 800 & 680 & 825 \\
\hline
\end{tabular}

Table 7 Antifungal activity of crud extracts isolated from bark and leaves of $P$. halepensis and $O$. europaea trees grown at the three levels of altitude in Al-Jabal Al-Akhdar (Libya) against B. cinerea

\begin{tabular}{|c|c|c|c|c|c|c|c|}
\hline \multirow[t]{2}{*}{ Crud extracts } & \multirow{2}{*}{ Altitude } & \multirow{2}{*}{$E C_{50}{ }^{a}(\mathrm{mg} / \mathrm{L})$} & \multicolumn{2}{|c|}{$\begin{array}{l}95 \% \text { confidence limits } \\
\text { (mg/L) }\end{array}$} & \multirow[t]{2}{*}{ Slope \pm SE } & \multirow[t]{2}{*}{ Intercept \pm SE } & \multirow{2}{*}{$\left(\chi^{2}\right)^{b}$} \\
\hline & & & Lower & Upper & & & \\
\hline \multirow{3}{*}{ P. halepensis bark } & $\mathrm{I}(\mathrm{I} 25 \mathrm{~m})$ & 127.3 & 66.82 & 200.82 & $1.979 \pm 0.151$ & $-4.165 \pm 0.347$ & $|8.48|$ \\
\hline & II(39Im) & |54.7| & 67.126 & $277.94 I$ & $1.938 \pm 0.143$ & $-4.242 \pm 0.337$ & 28.750 \\
\hline & $\mathrm{III}(85 \mathrm{Im})$ & 139.7 & 54.982 & 198.657 & $2.022 \pm 0.156$ & $-4.20 I \pm 0.355$ & 22.932 \\
\hline \multirow{3}{*}{ P. halepensis leaf } & $\mathrm{I}(\mathrm{I} 25 \mathrm{~m})$ & 119.2 & 63.679 & 185.537 & $2.115 \pm 0.162$ & $-4.392 \pm 0.366$ & 18.583 \\
\hline & II(39lm) & 134.2 & 86.291 & 191.65 & $2.247 \pm 0.166$ & $-4.780 \pm 0.378$ & 13.374 \\
\hline & $\mathrm{III}(85 \mathrm{Im})$ & 115.42 & 59.643 & 182.037 & $2.206 \pm 0.169$ & $-4.549 \pm .380$ & 20.478 \\
\hline \multirow{3}{*}{ O. europaea bark } & $\mathrm{I}(\mathrm{I} 25 \mathrm{~m})$ & 109.9 & 40.854 & $|84.9|$ & $2.324 \pm 0.183$ & $-4.705 \pm 0.404$ & 30.659 \\
\hline & II(39lm) & 101.16 & 47.784 & |79.38| & $2.347 \pm 0.187$ & $-4.716 \pm 0.410$ & 31.325 \\
\hline & $\mathrm{III}(85 \mathrm{Im})$ & 89.55 & 55.078 & 153.879 & $2.274 \pm 0.181$ & $-4.563 \pm 0.398$ & 17.359 \\
\hline \multirow{3}{*}{ O. europaea leaf } & $\mathrm{I}(\mathrm{I} 25 \mathrm{~m})$ & 117.14 & 18.95 & 260.947 & $2.254 \pm 0.173$ & $-4.663 \pm 0.389$ & 53.043 \\
\hline & II(39Im) & 7I.I & 11.829 & 139.282 & $1.495 \pm 0.140$ & $-2.768 \pm 0.320$ & 22.799 \\
\hline & III(85 Im) & 99.6 & 38.312 & 169.993 & $1.836 \pm .150$ & $-3.669 \pm 0.342$ & 21.802 \\
\hline
\end{tabular}

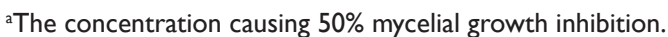

${ }^{\mathrm{b}}$ Chi-Square.

\section{Conclusion}

Acetone extracts from $P$. halepensis Mill (needles and bark) and $O$. europaea L. (leaves and bark), obtained from three different altitudes in the Al-Jabel Al- Akhdar, Libya, were analyzed by GC/MS and considered as potential natural antimicrobial agents against certain pathogenic bacteria and plant fungi. The results revealed differences in the yield of extracts and the chemical composition of different altitudes $(125,391$ and $851 \mathrm{~m}$ of sea level). Although the main components of all extracts are common, their percentages are different based on the tree species and the altitude level. These differences are the results of an adaptive process to particular ecologic conditions, which are in direct relation with the altitudes. O. europaea leaf and bark extracts showed good activity against the studied bacterial strains A. tumefaciens, E. carotovora, C. fascian and P. solanacearum and the fungus used $B$. cinerea. Additionally, the acetone extract from $P$. halepensis needles at level I showed good activity against $A$. tumefaciens. Based on these results, the acetone extracts from bark and leaves of $P$. halepensis and $O$. europaea could be suggested as alternative antimicrobials. However, as these tests have been done in vitro, the next step may be further investigations as in vivo on plants.

\section{Acknowledgements}

None.

\section{Conflict of interest}

The author declares no conflict of interest.

\section{References}

1. Al-Idrissi M, Sbeita A, Jebriel A, et al. Libya: Country report to the fao international technical conference on plant genetic resources. Tripoli, Libya; 1996. p. 1-29.

2. Hegazy A, Boulos L, Kabiel H, et al. Vegetation and species altitudinal distribution in al-jabal al-akhdar landscape, libya. Pak $J$ Bot. 2011;43:1885-1898. 
3. Elshatshat S, Mansour A. Disturbance of flora and vegetation composition of libya by human impacts: Costal region of al-jabal al-akhdar area as model. J Appl Sci Res. 2014;5(5):286-292.

4. Al-Sodany YM, Shehata M, Shaltout KH. Vegetation along an elevation gradient in al-jabal al-akhdar, Libya. Ecologia mediterranea. 2003;29:125-138.

5. El-Barasi YMM, Saaed MWB. Threats to plant diversity in the north eastern part of Libya (el-jabal el-akahdar and marmarica plateau). Journal of Environmental Science and Engineering A. 2013;2:41.

6. Attitalla IH, Alhasin AM, Nasib M, et al. Occurrence and microbiological characteristics of azospirillum strains associated with leguminous and non-leguminous plants in al jabal al akhdar eco-region, Libya. American-Eurasian Journal of Agricultural and Environmental Science. 2010;8(6):617-625.

7. Hamad H, Ibrahim H, Mariam H, et al. Comparative phytochemical and antimicrobial investigation of some plants growing in al jabal al-akhdar. JJ Nat Prod Plant Resour. 2011;1:15-23.

8. Fatope MO, Adoum OA, Takerda Y. Oleanene palmitate from ximenia Americana. Pharmaceut Biol. 2000;38(5):391-393.

9. Cakir A, Kordali S, Zengin H, et al. Composition and antifungal activity of essential oils isolated from hypericum hyssopifolium and hypericum heterophyllum. Flavour and Fragrance Journal. 2004;19(1):62-68.

10. Hafizoğlu H, Usta M. Chemical composition of coniferous wood species occurring in turkey. European Journal of Wood and Wood Products. 2005;63(1):83-85.

11. Quézel P, Médail F, Loisel R, et al. Biodiversity and conservation of forest species in the mediterranean basin. UNASYLVA-; 1999. p. 21-28.

12. Georgiadis T, Economidou E, Christodoulakis D. Flora and vegetation of the strofilia coastal area (nw peloponnesos-greece). Phyton. 1990;30:1536

13. Al-Snafi AE. Medical importance of cupressus sempervirens-a review IOSR Journal of Pharmacy. 2016;6(6):66-76.

14. Benavente-Garcia O, Castillo J, Lorente J, et al. Antioxidant activity of phenolics extracted from olea europaea 1. Leaves. Food Chemistry. 2000;68(4):457-462.

15. Bianco A, Uccella N. Biophenolic components of olives. Food Research International. 2000;33(6):475-485.

16. Tasioula-margari $\mathrm{M}$, Okogeri $\mathrm{O}$. Isolation and characterization of virgin olive oil phenolic compounds by HPLC/UV and GC-MS. Journal of food science. 2001;66(4):530-534.

17. Ahmed AM, Rabii NS, Garbaj AM, et al. Antibacterial effect of olive (olea europaea 1.) leaves extract in raw peeled undeveined shrimp (penaeus semisulcatus). International Journal of Veterinary Science and Medicine. 2014;2(1):53-56.

18. Lee OH, Lee BY. Antioxidant and antimicrobial activities of individua and combined phenolics in olea europaea leaf extract. Bioresour Technol. 2010;101(10):3751-3754.

19. Pereira AP, Ferreira IC, Marcelino F, et al. Phenolic compounds and antimicrobial activity of olive (olea europaea 1 . Cv. Cobrançosa) leaves. Molecules. 2007;12(5):1153-1162.

20. Korukluoglu M, Sahan Y, Yigit A, et al. Antibacterial activity and chemical constitutions of olea europaea 1. Leaf extracts. Journal of Food processing and preservation. 2010;34(3):383-396.

21. Soni M, Burdock G, Christian M, et al. Safety assessment of aqueous olive pulp extract as an antioxidant or antimicrobial agent in foods. Food and chemical toxico Food Chem Toxicol. 2006;44(7):903-915.
22. Sudjana AN, D’Orazio C, Ryan V, et al. Antimicrobial activity of commercial olea europaea (olive) leaf extract. Int $J$ Antimicrob Agents. 2009;33(5):461-463.

23. Taamalli A, Arráez-Román D, Zarrouk M, et al. The occurrence and bioactivity of polyphenols in tunisian olive products and by-products: A review. J Food Sci. 2012;77(4):R83-92.

24. Nora NB, Hamid K, Snouci M, et al. Antibacterial activity and phytochemical screening of olea europaea leaves from algeria. The Open Conference Proccedings Journal. 2012;3(Suppl 1-M11):66-69.

25. Quezel P. Taxonomy and biogeography of mediterranean pines (pinus halepensis and p. Brutia). Ecology, Biogeography and Management of Pinus halepensis and P brutia Forest Ecosystems in the Mediterranean Basin Backhuys. Leiden, Netherlands; 2000. p. 1-12.

26. Sabaté S, Gracia CA, Sánchez A. Likely effects of climate change on growth of quercus ilex, pinus halepensis, pinus pinaster, pinus sylvestris and fagus sylvatica forests in the mediterranean region. Forest ecology and management. 2002;162(1):23-37.

27. Tumen I, Sezer Senol F, Orhan IE. Evaluation of possible in vitro neurobiological effects of two varieties of cupressus sempervirens (mediterranean cypress) through their antioxidant and enzyme inhibition actions. Turk J Biochem. 2012;37(1):5-13.

28. Dob T, Berramdane T, Chelgoum C. Chemical composition of essential oil of pinus halepensis miller growing in algeria. Comptes Rendus Chimie. 2005;8(11-12):1939-1945.

29. Arianoutsou M, Neeman G. Post-fire regeneration of natural pinus halepensis forests in the east mediterranean basin. Ecology, Biogeography and Management of Pinus halepensis and P brutia Forest Ecosystems in the Mediterranean Basin Backhuys Publishers. Leiden, Netherlands; 2000. p. 269-290.

30. Asensio D, Owen SM, Llusia J, et al. The distribution of volatile isoprenoids in the soil horizons around pinus halepensis trees. Soil Biology and Biochemistry. 2008;40(12):2937-2947.

31. Fernandez C, Monnier Y, Ormeño E, et al. Variations in allelochemical composition of leachates of different organs and maturity stages of pinus halepensis. J Chem Ecol. 2009;35(8):970-979.

32. Fernandez C, Lelong B, Vila B, et al. Potential allelopathic effect of pinus halepensis in the secondary succession: An experimental approach. Chemoecology. 2006;16(2):97-105.

33. Roussis V, Petrakis PV, Ortiz A, et al. Volatile constituents of needles of five pinus species grown in greece. Phytochemistry. 1995;39(2):357-361.

34. Nam AM, Tomi F, Gibernau M, et al. Composition and chemical variability of the needle oil from pinus halepensis growing in corsica. Chem Biodivers. 2016;13(4):380-386.

35. Rodrigues AM, Mendes MD, Lima AS, et al. Pinus halepensis, p. Pinaster, p. Pinea and p. Sylvestris essential oils chemotypes and monoterpene hydrocarbon enantiomers, before and after inoculation with the pinewood nematode bursaphelenchus xylophilus. Chemistry \& Biodiversity. 2016;14(1):1-16

36. Macchioni F, Cioni P, Flamini G, et al. Chemical composition of essential oils from needles, branches and cones of pinus pinea, p. Halepensis, $p$. Pinaster and p. Nigra from central ltaly. Flavour and Fragrance Journal. 2003;18(2):139-143.

37. Blanch JS, Penuelas J, Sardans J, et al. Drought, warming and soil fertilization effects on leaf volatile terpene concentrations in pinus halepensis and quercus ilex. Acta Physiologiae Plantarum. 2009;31:207-218.

38. Figueiredo AC, Barroso JG, Pedro LG, et al. Factors affecting secondary metabolite production in plants: Volatile components and essential oils Flavour and Fragrance Journal. 2008;23(4):213-226. 
39. Clarke C. Examining the antimicrobial activity of plant extracts. Student Research Week Proceedings. 2016.

40. Dekdouk N, Malafronte N, Russo D, et al. Phenolic compounds from olea europaea 1. Possess antioxidant activity and inhibit carbohydrate metabolizing enzymes in vitro. Evidence-Based Complementary and Alternative Medicine. 2015;2015:684925.

41. Varo A, Mulero-Aparicio A, Adem M, et al. Screening water extracts and essential oils from mediterranean plants against verticillium dahliae in olive. Crop Protection. 2017;92:168-175.

42. Shawahna R, Jaradat NA. Ethnopharmacological survey of medicinal plants used by patients with psoriasis in the west bank of palestine. BMC Complementary and Alternative Medicine. 2017;17(1):4.

43. Sparkman OD, Penton Z, Kitson FG. Gas chromatography and mass spectrometry: A practical guide. In: David Sparkman O editor. 2nd ed. CA, USA: Academic Press; 2011. 632 p.

44. Hites RA. Gas chromatography mass spectrometry. Handbook of instrumental techniques for analytical chemistry. 1997. p. 609-626.

45. Ali HM, Salem MZ, Mohamed NH. Evaluation of extracts from different parts of some tree species against the growth of human bacterial pathogens. J Pure Appl Microbiol. 2014;8:149-154.

46. Anäs E, Ekman R, Holmbom B. Composition of nonpolar extractives in bark of norway spruce and scots pine. Journal of Wood Chemistry and Technology. 1983;3(2):119-130.

47. Ekman R, Holmbom B. Analysis by gas chromatography of the wood extractives in pulp and water samples from mechanical pulping of spruce. Nordic Pulp and Paper Research Journal. 1989;4(1):16-24.

48. Davies N. Gas chromatographic retention indices of monoterpenes and sesquiterpenes on methyl silicon and carbowax 20m phases. Journal of Chromatography A. 1990;503:1-24.

49. Adams RP. Identification of essential oil components by gas chromatography. Mass Spectrometry. 1995. p. 237-243.

50. Eloff JN. A sensitive and quick microplate method to determine the minimal inhibitory concentration of plant extracts for bacteria. Planta Medica. 1999;64(8):711-713.

51. Yajko DM, Madej JJ, Lancaster MV, et al. Colorimetric method for determining mics of antimicrobial agents for mycobacterium tuberculosis Journal of Clinical Microbiology. 1995;33(9):2324-2327.

52. Badawy ME, Rabea EI, Taktak NE. Antimicrobial and inhibitory enzyme activity of n-(benzyl) and quaternary n-(benzyl) chitosan derivatives on plant pathogens. Carbohydrate polymers. 2014;111:670-682.

53. Finney DJ. Probit analysis. 3rd ed. USA: Cambridge University Press; 1971. $350 \mathrm{p}$.

54. Faiza I, Wahiba K, Nassira G, et al. Antibacterial and antifungal activities of olive (olea europaea 1.) from algeria. J Microbiol Biotech Res. 2011;1:69-73.

55. Fekih N, Allali H, Merghache S, et al. Chemical composition and antibacterial activity of pinus halepensis miller growing in west northern of algeria. Asian Pac J Trop Dis. 2014;4(2):97-103.

56. Véga C, Hamrouni A, El Mokhtari S, et al. Ptrees: A point-based approach to forest tree extraction from lidar data. International Journal of Applied Earth Observation and Geoinformation. 2014;33:98-108.

57. Fuentes J, Vernhe M, Cuetara E, et al. Tannins from barks of pinus caribaea protect escherichia coli cells against DNA damage induced by $\gamma$-rays. Fitoterapia. 2006;77(2):116-120.

58. Kozan E, Küpeli E, Yesilada E. Evaluation of some plants used in turkish folk medicine against parasitic infections for their in vivo anthelmintic activity. Journal of ethnopharmacology. 2006;108(2):211-216.
59. Baba Aissa F. Medicinal plants in algeria. Identification, description of active ingredient properties and traditional use of common plants in Algeria Algiers: Bouchene and Ad Diwan; 1991. 181 p.

60. Pasqualini V, Robles C, Garzino S, et al. Phenolic compounds content in pinus halepensis mill. Needles: A bioindicator of air pollution. Chemosphere. 2003;52(1):239-248.

61. Cheikh-Rouhou S, Hentati B, Besbes S, et al. Chemical composition and lipid fraction characteristics of aleppo pine (pinus halepensis mill.) seeds cultivated in tunisia. Food sci tech int. 2006;15(5):407-416.

62. Ogunwande IA, Olawore NO, Adeleke KA, et al. Chemical composition of the leaf volatile oil of psidium guajava 1. Growing in nigeria. Flavour and fragrance journal. 2003;18(2):136-138.

63. Bock M, Thorstensen EB, Derraik JG, et al. Human absorption and metabolism of oleuropein and hydroxytyrosol ingested as olive (olea europaea 1.) leaf extract. Mol Nutr Food Res. 2013;57(11):2079-2085.

64. Owen R, Haubner R, Würtele G, et al. Olives and olive oil in cancer prevention. Eur J Cancer Prev. 2004;13(4):319-326.

65. Keskin D, Ceyhan N, Ugur A, et al. Antimicrobial activity and chemical constitutions of west anatolian olive (olea europaea 1.) leaves. Journal of Food, Agriculture \& Environment. 2012;10(2):99-102.

66. Al-Othman AM, Hussain I, Khan H, et al. Phytochemical analysis and biological activities of selected medicinal plants. Journal of Medicinal Plants Research. 2012;6:4005-4010.

67. Voulgaridis E, Grigoriou A, Passialis C. Investigations on bark extractives of pinus halepensis mill. Holz als Roh-und werkstoff. 1985;43(7):269272.

68. Elvira S, Alonso R, Castillo FJ, et al. On the response of pigments and antioxidants of pinus halepensis seedlings to mediterranean climatic factors and long-term ozone exposure. New Phytologist. 1998;138(3):419-432.

69. Ben Youssef S, Fakhfakh J, Tchoumtchoua J, et al. Efficient purification and complete nmr characterization of galactinol, sucrose, raffinose, and stachyose isolated from pinus halepensis (aleppo pine) seeds using acetylation procedure. Journal of Carbohydrate Chemistry. 2016;35(4):224 237.

70. Romani A, Pinelli P, Ieri F, et al. Sustainability, innovation, and green chemistry in the production and valorization of phenolic extracts from olea europaea 1. Sustainability. 2016;8(10):1002.

71. Schaide T, Martín-Vertedor D, Hernández A, et al. Antimicrobial activity of olive (olea europaea) leaf extract to be used during the elaboration process of green table olives. Microbes in the Spotlight: Recent Progress in the Understanding of Beneficial and Harmful Microorganisms. USA: BrownWalker Press; 2016. 494 p.

72. Zeriouh W, Nani A, Belarbi M, et al. Phenolic extract from oleaster (olea europaea var. Sylvestris) leaves reduces colon cancer growth and induces caspase-dependent apoptosis in colon cancer cells via the mitochondrial apoptotic pathway. PLOS ONE. 2017;12(2):e0170823.

73. Korukluoglu M, Sahan Y, Yigit A, et al. In vitro antibacterial activity of olive leaf (olea europaea 1.) extracts and their chemical characterization. Abs. 2010. p. 563-565.

74. Gumgumjee NM, Hajar AS. Antimicrobial activities and phytochemica properties of saudi olea europaea subsp. Cuspidata. Life Science Journal. 2014. $11 \mathrm{p}$.

75. Aliabadi MA, Darsanaki RK, Rokhi ML, et al. Antimicrobial activity of olive leaf aqueous extract. Annals of Biological Research. 2012;3(8):4189-4191.

76. Markin D, Duek L, Berdicevsky I. In vitro antimicrobial activity of olive leaves. Mycoses. 2003;46(3-4):132-136. 
77. Omar SH. Oleuropein in olive and its pharmacological effects. Sci Pharm. 2010;78(2):133-154.

78. Dellavalle PD, Cabrera A, Alem D, et al. Antifungal activity of medicinal plant extracts against phytopathogenic fungus alternaria spp. Chilean Journal of Agricultural Research. 2011;71(2):1-9.

79. Filip R, Davicino R, Anesini C. Antifungal activity of the aqueous extract of ilex paraguariensis against malassezia furfur. Phytother Res. 2010;24(5):715-719.

80. Nascimento GG, Locatelli J, Freitas PC, et al. Antibacterial activity of plant extracts and phytochemicals on antibiotic-resistant bacteria. Brazilian journal of microbiology. 2010;31(4):247-256.

81. Kähkönen MP, Hopia AI, Vuorela HJ, et al. Antioxidant activity of plant extracts containing phenolic compounds. J Agric Food Chem. 1999;47(10):3954-3962.
82. Rauha JP, Remes S, Heinonen M, et al. Antimicrobial effects of finnish plant extracts containing flavonoids and other phenolic compounds. Int $J$ Food Microbiol. 2000;56(1):3-12.

83. Tamokou JDD, Tala MF, Wabo HK, et al. Antimicrobial activities of methanol extract and compounds from stem bark of vismia rubescens. $J$ Ethnopharmacol. 2009;124(3):571-575.

84. Abdelgaleil S, Badawy M, Suganuma T, et al. Antifungal and biochemical effects of pseudoguaianolide sesquiterpenes isolated from Ambrosia aritima L. African Journal of Microbiology Research. 2011;5(21):33853393.

85. Tekaya-Karoui A, Boughalleb N, Hammami S, et al. Chemical composition and antifungal activity of volatile components from woody terminal branches and roots of tetraclinis articulate (vahl.) masters growing in tunisia. African Journal of Plant Science. 2011;5(2):115-122. 